\title{
EPIDEMICS OF GASTRO-ENTERITIS ASSOCIATED WITH ESCH. COLI O119 INFECTION
}

\author{
BY \\ K. HUGH-JONES* and G. I. M. ROSS $\dagger$ \\ From the Westminster Children's Hospital and Westminster Medical School
}

(RECEIVED FOR PUbLICATION JUNE 23, 19.58)

\section{Introduction}

Three outbreaks of gastro-enteritis associated with the presence of Esch. coli $\mathrm{O} 119$ in the stools occurred among the infants in a baby ward between September, 1954, and February, 1956. In these epidemics altogether 45 infants were found to be infected. During the whole period the organism was also isolated from 13 out-patients and three children in other wards. This paper describes the frequency with which the organism was found in the stools of those at risk, the association between this finding and symptoms, some biochemical and antigenic characteristics of the Esch. coli O119, together with the results of antibiotic and sulphonamide sensitivity tests and a note of comparison with the clinical response.

\section{Bacteriological Methods}

Swabs of faeces were taken from each infant on admission and thereafter on every Monday and Thursday while in the ward.

Cultures. The routine swabs were plated on MacConkey agar and desoxycholate citrate agar. Swabs from those known to have diarrhoea were inoculated also into selenite $F$ broth from which subcultures were made on to desoxycholate citrate agar after 24 hours' incubation. All the Esch. coli $\mathrm{O} 119$ strains isolated were stored on Dorset egg slopes for further tests.

Antigenic Identification. (a) O Antigens. During the first year of this investigation all faecal specimens were examined for the presence of 10 different $O$ types of Esch. coli. These types were O25, O26, O55, O86, O111, O114, O119, O125, O126 and O128. The antisera initially used for this purpose were most kindly supplied by Dr. J. Smith of Aberdeen. Later, sera prepared in this laboratory and polyvalent and individual $O$ antisera supplied by the Standards Laboratory of the Central Public Health Laboratory were also used.

Mixtures of lactose-fermenting colonies of gram negative bacilli on MacConkey agar were tested for

\footnotetext{
* St. Bartholomew's Hospital, London, E.C.1.
}

$\dagger$ Ashford Hospital, Ashford, Middlesex. agglutination on Murray slides with these sera. Pure colonies of the various types of Esch. coli were then selected by slide agglutination, if necessary after further subculture. Their identity was finally determined by tube agglutination tests showing that, after boiling for one hour to destroy $\mathrm{K}$ antigen, they were agglutinated to the titre of the $\mathrm{O}$ antiserum. One of the earliest strains of O119 isolated in the first epidemic was kindly confirmed as such by Dr. Joan Taylor.

After the first year of this study tests were made routinely only for Esch. coli types O26, O55, O111, 0119 and $\mathrm{O} 128$ as the numbers of the other types encountered did not justify the considerable extra work involved in searching for them. In all cases of gastro-enteritis, however, when tests were negative for these five types of Esch. coli and for salmonellae and shigellae, the additional antisera against the other five Esch.coli types were used to try and identify a possible pathogen in the stools.

(b) H ANTigens. One strain of $\mathrm{O} 119$ isolated in the first epidemic was found by Dr. Joan Taylor to be type H6. Then, using antiserum kindly provided by Dr. Taylor, other strains were typed by tube agglutination. Motility was readily obtained with only one or two passages through Craigie tubes.

Biochemical Tests. The fermentative ability of all the strains of typable Esch. coli isolated during the period of the study was tested in $1 \%$ peptone water sugars. Sugars were incubated up to 21 days if acid had not been produced before that time. Tests such as indole, Voges-Proskauer and methyl red were carried out by the standard procedures described in Topley and Wilson (1946).

Sensitivity Tests. Antibiotic sensitivity tests were performed immediately after the isolation of each strain of typable Esch. coli using tablets (Evans Medical Supplies Limited) containing penicillin, streptomycin, aureomycin, terramycin and chloramphenicol. Subsequently the exact bacteriostatic concentrations of these antibiotics, and of neomycin, polymyxin, tetracycline and sulphathiazole were determined by plating each organism on agar containing doubling concentrations of these agents. The sulphonamide sensitivity tests were made 
using the medium recommended by Jewell and Pearmain (1954) but with $2 \%$ horse blood added.

\section{General Background}

These epidemics occurred in the baby ward of Westminster Children's Hospital. The ward consisted of 11 separate cubicles, one of which sometimes took two infants and seven of which were nursing-mother flats. All these cubicles were entirely separate rooms, each with a wash basin. Individual nurse's and doctor's gowns were provided for each baby and the usual barrier nursing techniques were used whenever attending to the children. Every effort was made to avoid admitting cases of gastro-enteritis to the ward, but during the period under review four infants were finally diagnosed as such and a pathogenic Esch. coli other than $\mathrm{O} 119$ demonstrated in their faeces. Two were infected with an $\mathrm{O55}$, one with an 0111 and one with an 0128 .

\section{Clinical Findings During the Survey}

First Epidemic. Preliminary Survey. During July and August, 1954, several babies in the ward developed gastro-enteritis and in September testing for pathogenic Esch. coli was first begun. Four children (Cases 1-4), who had or had had gastroenteritis recently, were found to be excreting Esch. coli 0119 . Because of this the ward was shut and this investigation begun.

MaIn SuRveY. The ward was closed for four days in Week 2 (Fig. 1) when each cubicle was scrubbed, fumigated with formaldehyde and then aired for 24 hours. On opening the ward entirely new patients were admitted. From this point onwards the routine swabbing on admission, and thereafter twice weekly, was begun and daily enquiry made regarding each infant's stools. In all, some 370 swabs were examined from 51 infants. During the first week that the ward was open (Week 3) all the children had negative swab results.
Within 12 days of reopening the ward (Week 4) Esch. coli $\mathrm{O} 119$ was demonstrated in the stools of a breast fed baby (Case 5) and the steady spread of the infection can be followed from case to case in Fig. 1. A further 22 babies were infected. Case 3 was readmitted in the ninth and reinfected in the eleventh week (Fig. 1) bringing the total to the

\section{FIRST OII9 EPIDEMIC}

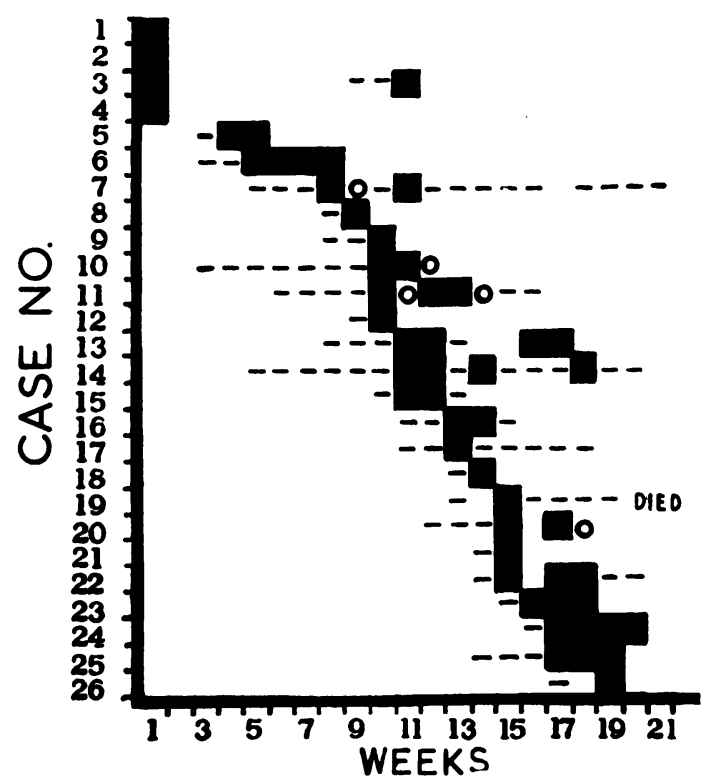

FIG. 1.-The results of culture of the faeces in each case in each week of the epidemic: Esch. coli O119; - No typable Esch. coli; O No Esch. coli.

23 cases shown in Table 1. Fig. 2 shows the number of babies in the ward during each week, the number with positive cultures and the number with definite gastro-enteritis.

Once the organism had been demonstrated again after reopening the ward it will be seen that at least

TABLE 1

\begin{tabular}{|c|c|c|c|c|c|c|c|c|c|}
\hline \multirow{2}{*}{\multicolumn{2}{|c|}{ Group }} & & \multicolumn{3}{|c|}{ Criteria } & \multicolumn{4}{|c|}{ Number of Infants } \\
\hline & & & \multirow{2}{*}{$\frac{\begin{array}{c}\text { Admission } \\
\text { Swab }\end{array}}{\text { Negative }}$} & \multirow{2}{*}{$\begin{array}{c}\begin{array}{c}\text { Further } \\
\text { Swabs }\end{array} \\
\text { Negative }\end{array}$} & \multirow{2}{*}{\begin{tabular}{|c|}
$\begin{array}{c}\text { Clinical } \\
\text { Evidence of } \\
\text { Gastro-enteritis }\end{array}$ \\
None
\end{tabular}} & \multirow{2}{*}{$\begin{array}{c}\begin{array}{c}\text { First } \\
\text { Epidemic }\end{array} \\
28\end{array}$} & \multirow{2}{*}{$\begin{array}{c}\begin{array}{c}\text { Second } \\
\text { Epidemic }\end{array} \\
33\end{array}$} & \multirow{2}{*}{$\begin{array}{c}\begin{array}{c}\text { Third } \\
\text { Epidemic }\end{array} \\
14\end{array}$} & \multirow{2}{*}{$\frac{\text { Total }}{75}$} \\
\hline I & .. & .. & & & & & & & \\
\hline II & . & .. & Negative & Positive & None & 8 & 4 & 2 & 14 \\
\hline III & $\ldots$ & .. & Negative & Positive & Mild & 5 & 2 & 0 & 7 \\
\hline IV & $\ldots$ & .. & Negative & Positive & Definite & 10 & 8 & 2 & 20 \\
\hline \multicolumn{6}{|c|}{ Total infants at risk in each epidemic } & 51 & 47 & 18 & 116 \\
\hline
\end{tabular}




\section{FIRST OII9 EPIDEMIC}

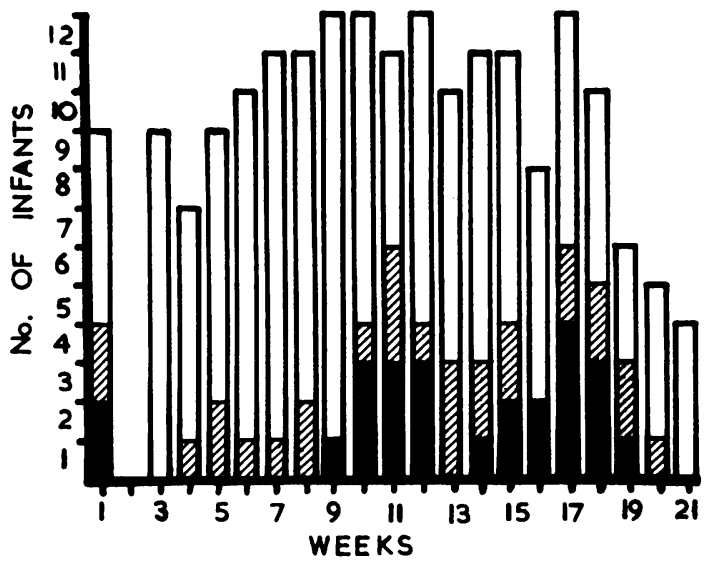

FIG. 2.-The total number of infants, those with Esch. coli O119 in faeces and those with gastro-enteritis, in each week of the epidemic: Number with definite gastro-enteritis; V/. Number with Esch. coli O119 in faeces; $\square$ Total number of infants in ward.

one child was excreting it in each of the remaining weeks of the epidemic. There were two peaks (Weeks 11 and 17) during which $50 \%$ of the children had positive cultures. Because of the second peak of cross-infection no further babies were admitted to the ward, and so the epidemic died out at the end of January, 1955, after more than 20 weeks and the ward was then closed. During this epidemic one child attending Out-patients with gastro-enteritis was found to be infected with Esch. coli O119.

Interim Period between First and Second Epidemics. The ward was shut for two weeks for thorough cleaning and repainting; during this time there was a vigorous overhauling of nursing procedures and structural improvements were planned. Although
SECOND OII9 EPIDEMIC

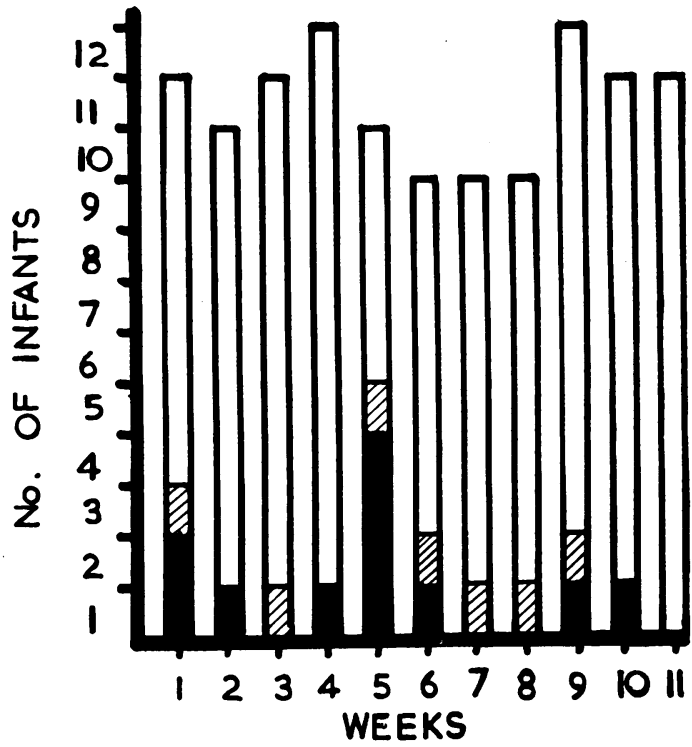

FIG. 4.-The total number of infants, those with Esch. coli 0119 in faeces and those with gastro-enteritis, in each week of the epidemic: - Number with definite gastro-enteritis; $/ 2$ Number with Esch. coli $\mathrm{O} 119$ in faeces; $\square$ Total number of infants in ward.

no serious deficiencies in the methods of preventing cross-infections were brought to light, the discussion and general awareness no doubt improved individual techniques. It was also decided for the future that even the mildest case of gastro-enteritis due to pathogenic Esch. coli in that ward should be treated energetically with antibiotics.

The ward was reopened in February, 1955, and no case of Esch. coli 0119 infection was detected for 15 weeks. During this period some 300 faecal samples from 48 infants were examined.

Second Epidemic. On June 6, 1955, two babies (Cases 27 and 28) developed gastro-enteritis and were found to have Esch. coli O119 in their stools on the same day (Week 1, Fig. 3). Fig. 3 shows the spread of the ininfection from case to case during the 10 weeks that the epidemic lasted. The organism was demonstrated in the faeces of at least one infant during each week except Week 8. During this week Case 38 continued to have diarrhoea though no Esch. coli was grown from his faeces; terramycin was being given at that time. Fig. 4
FIG. 3.-The results of culture of the faeces in each case in each week of the epidemic: - Esch. coli O119; - No typable Esch. coli; O No Esch. coli. 
shows the number of babies in the ward, the number with positive cultures for Esch. coli $\mathrm{O} 119$ and the number with definite gastro-enteritis each week. The peak incidence of infection was in Week 5 when $50 \%$ of the children had positive cultures. In all, 14 infants were found to be infected.

The source of this infection was not known. It was unlikely that the organism had remained alive in the ward during the 18 weeks since the previous epidemic. The most likely origin was Case 27 who was admitted with whooping cough and treated with terramycin for the first three weeks. Towards the end of this course of treatment the child had some diarrhoea but this then stopped. Two weeks later, however, it recurred and Esch. coli $\mathrm{O} 119$ was first demonstrated in the faeces. Alternatively the organism may have been carried by a member of the staff from the first epidemic; or it may have been introduced into the ward, directly by the admission of an unidentified carrier, or indirectly by a member of the staff from a child with diarrhoea attending Out-patients. However, as no Esch. coli 0119 was demonstrated either in the ward or from Outpatients before June 6 the source of infection must remain uncertain. During the epidemic the organism was found in the faeces of one infant in another ward and of five children, two in one family, attending Out-patients. It seems possible that the epidemic was part of a more widespread infection in the locality. The epidemic died out in the tenth week and thereafter till the ward was closed in Week 12 for structural alterations, Esch. coli 0119 was not again demonstrated. During this epidemic some 180 faecal specimens from 47 infants in the ward were examined.

Interim Period between Second and Third Epidemics. This period was of 26 weeks during which over 800 faecal samples were examined. Eight infants were found to be infected with Esch. coli O119. One was admitted to a different ward from that in which the epidemics occurred and the others were out-patients. Seven had attended because of gastro-enteritis, the eighth was a 4-yearold symptom-free contact. Six of these cases occurred during November, 1955.

Third Epidemic. This epidemic began in February, 1956, and continued for 10 days. Four infants only in the baby ward were infected out of 18 at risk. One of these had been in the ward 10 days previously and presented with diarrhoea as an out-patient five days after the end of the epidemic. He was found to be excreting Esch. coli O119. It seems likely that he was infected while in hospital and only developed symptoms and positive stools after discharge. The infection appeared to have been introduced by an infant who was admitted with otitis externa. The first swab taken on admission showed the presence of the organism. This child was discharged home after five days in hospital. She was still excreting the organism in her stools but was always without any symptoms of infection. The other three infants had negative stools on admission and were presumably infected from the first child. Two of them had definite gastro-enteritis.

\section{General Features}

Incidence of Gastro-enteritis and Mortality in the Infected Infants. It can be seen from Table 1 that during the three epidemics in the ward 41 infants were found to be infected out of 116 at risk, and of those infected seven had mild symptoms and 20 definite gastro-enteritis. In this analysis Cases 1 to 4 are not included as they occurred during the preliminary survey.

In the first epidemic one child died of gastroenteritis. In the second two died, both with severe congenital abnormalities. One had a myelomeningocoele and hydrocephalus and his death was accelerated by gastro-enteritis. The other had congenital heart disease and died aged 12 days in congestive heart failure.

Carrier State. The second group in Table 1 of 14 children who were excreting the organism but remained symptom-free supports the suggestion that a carrier state exists as it does in other intestinal infections. The finding of the two older symptomfree children aged 4 and 6 in Out-patients also supports this. Although these children are well in themselves they are a danger to others. This is especially so because the organism can often be demonstrated in almost pure culture from their stools. Such a child seemed to be the origin of the third epidemic.

Incubation Period. To try and estimate the incubation period the time relationship between the first positive culture and the development of symptoms was studied, and also the length of time at risk was calculated, i.e. in the ward before the first positive culture developed. Out of the 20 infants with definite gastro-enteritis, five developed symptoms on the day of the first positive culture, four one day after, two two days after and one three, four, nine, 10 and 11 days after. Four developed symptoms before their first positive culture, one on the day before and the others on the fifth, sixth and seventh days before. 

weekly, the fact that 13 out of the 20 developed symptoms within four days of the organism being demonstrated suggests a short incubation period. This is supported by the fact that $60 \%$ of those that did become infected were found to be excreting the organism within a fortnight, and $20 \%$ within five days, of exposure to infection in the ward.

Age. The age incidence in the epidemics can be seen in Fig. 5. Because this ward was for babies there were more children in the youngest age group; nearly $80 \%$ of the admissions were under 6 months. Most of those that became infected did so during their second to fifth months of life-a time when infants are particularly susceptible to infection, which may be related to the low level of gamma globulin in their blood. The oldest child whom we found to be infected with an $\mathrm{O} 119$ was aged 6 years; he was symptom free. The oldest with symptoms was aged $2 \frac{1}{2}$ years. Both were out-patients.

Feeding. About one-fifth of the 116 infants at risk were entirely breast fed while in hospital but of the 41 infected infants only one was breast fed and that child was symptom-free (Case 5). Although the mothers were nearly always admitted with their babies, the routine nursing procedures were still carried out by the staff.
Remembering that cultures were made only twice

Treatment. FIRST EPIDEMIC. Systematic treatment with sulphonamides or antibiotics of every infant found to be infected with $\mathrm{O} 119$ was not given, as the policy of treating all cases however mild, or all carriers, had not yet been accepted. Several infants received more than one course of treatment with one or more drugs while in hospital. These courses were given as treatment either for the original cause of admission or for gastroenteritis.

Nine infants received sulphonamide orally, two streptomycin orally and seven penicillin systemically; all continued to excrete the organism while on treatment. One infant received chloramphenicol orally; he had negative swabs during treatment but was found to be excreting the organism again within seven days of stopping the drug.

SECOND EPIDEMIC. Four infants were discharged from hospital within a day or so of the organism being discovered in their stools and a fifth died; these were all untreated.

Seven infants with Esch. coli O119 infection were treated with terramycin and two with aureomycin followed by terramycin. The dosage of terramycin ranged from 10-16 mg./lb./day (mean $12 \mathrm{mg}$./lb./day) for four to 27 days (mean 12 days). In the nine treated patients all types of Esch. coli disappeared completely from the stools (Fig. 3). Once the stools
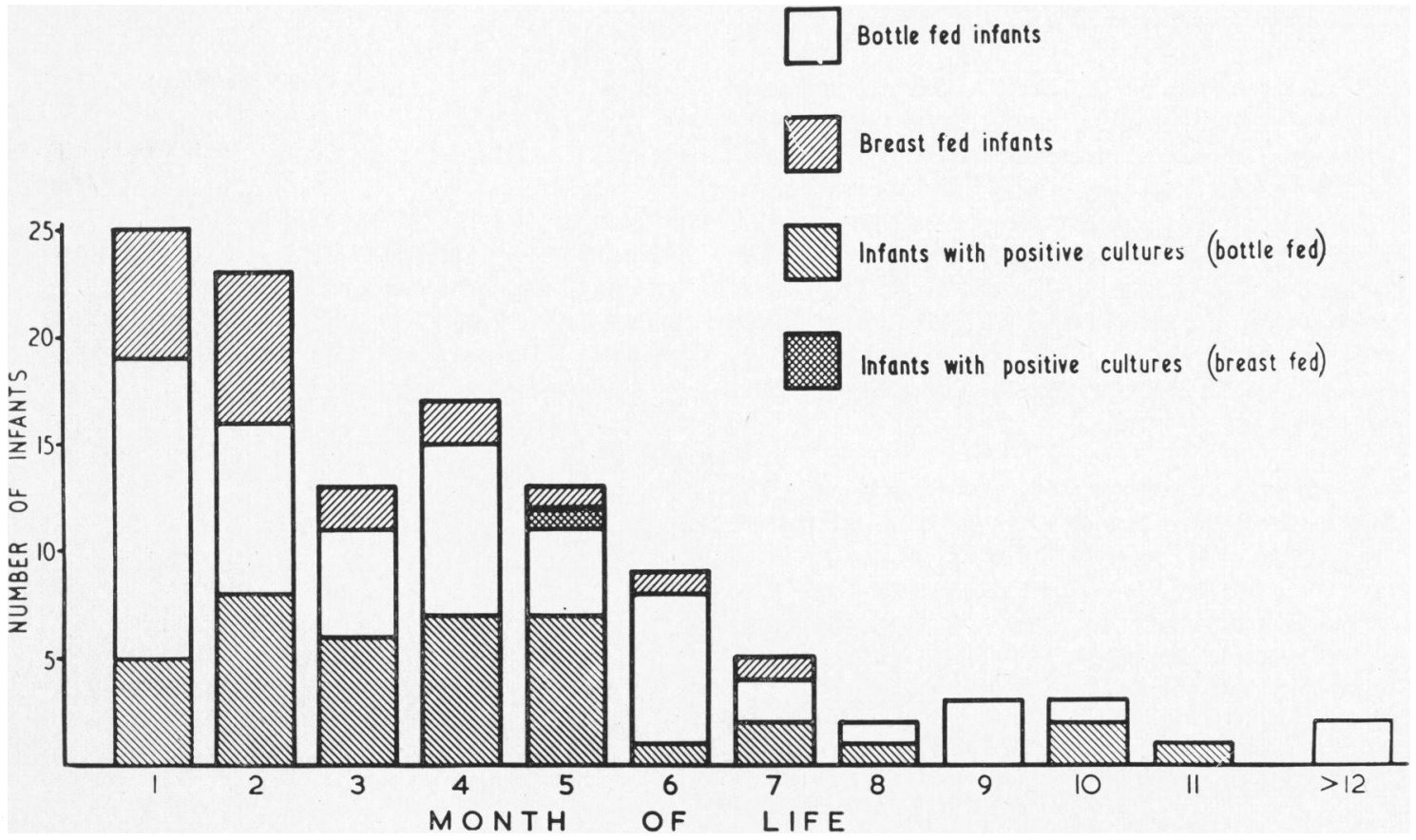

FIG. 5 - The age incidence of all the infants in the three epidemics, those with positive cultures and those breast or bottle fed. 
had become negative for $\mathrm{O} 119$ they remained so during the time the infants were in hospital.

THIRD EPIDEMIC. The two children with symptoms were given terramycin, one receiving $50 \mathrm{mg}$./lb./ day, the other $120 \mathrm{mg}$./lb./day. In both the cultures became negative. One had previously been treated with sulphonamide (125 mg./lb./day) for nine days with no effect.

Sensitivity of the Esch. coli 0119 Strains to Antibiotics and Sulphonamides. The sensitivity of the Esch. coli $\mathrm{O} 119$ strains isolated from 53 of the 61 infected infants were tested. All 53 strains had similar sensitivities. The bacteriostatic concentrations of the different drugs are shown in Table 2 .

TABLE 2

SENSITIVITY OF 53 STRAINS OF ESCH. COLI O119

\begin{tabular}{|c|c|c|c|c|c|c|c|c|c|}
\hline \multirow{3}{*}{ Drug } & \multicolumn{9}{|c|}{$\begin{array}{l}\text { Number of Strains Completely Inhibited } \\
\text { by Lowest Concentration of Drug }\end{array}$} \\
\hline & \multicolumn{7}{|c|}{ ( $\mu \mathrm{g}$. per ml. or units* per ml.) } & \multicolumn{2}{|c|}{$\begin{array}{l}\text { (mg. per } \\
100 \mathrm{ml} .)\end{array}$} \\
\hline & 1 & 2 & 4 & 8 & 16 & 50 & 100 & 512 & 1024 \\
\hline $\begin{array}{l}\text { Polymyxin* } \\
\text { Terramycin } \\
\text { Tetracycline } \\
\text { Chloramphenicol } \\
\text { Aureomycin } \\
\text { Streptomycin } \\
\text { Neomycin } \\
\text { Penicillin* } \\
\text { Sulphathiazole }\end{array}$ & 22 & $\begin{array}{r}31 \\
9 \\
19\end{array}$ & $\begin{array}{r}41 \\
30 \\
24 \\
11 \\
1 \\
12\end{array}$ & $\begin{array}{r}3 \\
4 \\
29 \\
31 \\
27 \\
41\end{array}$ & $\begin{array}{l}11 \\
25\end{array}$ & 28 & 25 & 11 & 42 \\
\hline
\end{tabular}

All were sensitive to therapeutic concentrations of polymyxin, terramycin, aureomycin, tetracycline, chloramphenicol, streptomycin and neomycin and all were resistant to penicillin and sulphathiazole.

In view of the resistance to the sulphonamide it is not surprising that drugs of this group proved so ineffective during the first epidemic. Terramycin given during the second and third epidemics proved effective in eradicating the organisms from the stools. Yet in spite of this the second epiciemic continued for 10 weeks.

Biochemical Characteristics of the Esch. coli 0119 Strains Isolated. Strains isolated from 53 infants were tested. These were the same strains as those on which the sensitivity tests were made. All gave identical reactions. Glucose, maltose, mannitol, lactose, sucrose, arabinose and xylose were fermented with acid and gas production within usually three days. Dulcitol was fermented with acid and gas production after two to 10 days. Variable times in the fermentation of dulcitol were found with even the same strains in several different batches of dulcitol peptone waters. Sorbitol was fermented after one day. Adonitol, inositol, inulin and rhamnose were not fermented in 21 days. All strains were indole positive, urease negative, methyl red positive, Voges-Proskauer negative and failed to liquefy gelatin. Tests for mucus production and haemolysis were negative.

H Antigen Type of the Esch. coli O119. One of the earliest strains isolated in the first epidemic was found to be type H6 by Dr. Joan Taylor. We subsequently typed 57 strains isolated from different infants during the period of the investigation and found all to be type $\mathrm{H} 6$.

Bacteriological Findings in the Whole Period of the Investigation. The findings in 1,044 specimens from 400 children studied during the three epidemic periods are summarized in Table 3. During these

TABLE 3

FINDINGS IN 1044 FAECAL SPECIMENS FROM 400 INFANTS EXAMINED DURING THE THREE ESCH. COLI O119 EPIDEMICS

\begin{tabular}{|c|c|c|c|c|}
\hline & \multicolumn{2}{|c|}{ Baby Ward } & \multirow{2}{*}{$\begin{array}{l}\text { Other } \\
\text { Wards }\end{array}$} & \multirow{2}{*}{$\begin{array}{r}\text { Out- } \\
\text { patients }\end{array}$} \\
\hline & $0119+$ ve & $0119-$ ve & & \\
\hline $\begin{array}{l}\text { Infants (No.): } \\
\text { studied } \\
\text { with Esch. coli O119 .. } \\
\text { with other pathogenic } \\
\text { types of Esch. coli ... }\end{array}$ & $\begin{array}{r}45 \\
45 \\
5\end{array}$ & $\begin{array}{r}75 \\
0 \\
6\end{array}$ & $\begin{array}{r}66 \\
2 \\
8\end{array}$ & $\begin{array}{r}214 \\
6 \\
15\end{array}$ \\
\hline $\begin{array}{l}\text { Specimens (No.): } \\
\text { totai examined } \\
\text { with Esch. coli O119 } \\
\text { with no Esch. coli } \\
\text { with other pathogenic } \\
\text { types of Esch. coli }\end{array}$ & $\begin{array}{r}412 \\
105 \\
80\end{array}$ & $\begin{array}{r}186 \\
0 \\
30\end{array}$ & $\begin{array}{r}116 \\
13 \\
14\end{array}$ & $\begin{array}{r}330 \\
9 \\
61\end{array}$ \\
\hline
\end{tabular}

periods a total of 127 specimens from 53 children were found to contain $\mathrm{O} 119$ while about $15 \%$ contained no Esch. coli of any type, usually because of antibiotic or sulphonamide therapy. In the intervals between the three epidemics another 1,224 specimens from 418 children were examined. Of these specimens 260 contained no Esch. coli and eight out of 72 specimens with pathogenic types of Esch. coli contained 0119 . In addition 782 faecal swabs from 76 newly born infants in three different maternity units, kindly provided by Dr. I. M. Anderson, were examined. These swabs were taken daily from birth till discharge from hospital. In only one of these swabs, taken from a baby without symptoms on the tenth day after birth, was a typable Esch. coli found and this was an $\mathrm{O} 128$.

Incidence of Other Types of Esch. coli. The incidence of other types of Esch. coli at Westminster Children's Hospital during the whole period of the 
study is shown in Table 4 . In all, 60 infants were found to be infected, of whom 18 were in the baby ward. During the first epidemic five of the 26 infants with 0119 infection in the baby ward were found to be infected with another of the 10 types of Esch. coli for which tests were being made. At some stage during their stay in hospital three (Cases 17, 20 and 24) were infected with 0111 and two with 0128 (Cases 5 and 14). One patient (Case 20) was found to be excreting 0111 on admission and subsequently infected the other two; one of these was found to be excreting both 0111 and $\mathrm{O} 119$ at the same time. The $\mathrm{O} 128$ was introduced by another infant who at no time excreted 0119.

Other types of Esch. coli known to be associated with gastro-enteritis in infants were isolated from 12 other infants in the baby ward who were at no time found to be infected with O119. Esch. coli O128 was most common.

During the first interim period three of the five in-patients with 0128 infection were in the baby ward and the organism appeared to have spread from one to another.

In the second epidemic none of the infants who were infected with $\mathrm{O} 119$ were found to have any other typable Esch. coli in their faeces. Three other infants in the baby ward and 11 others were found to be excreting one or other of the 10 types as shown in Table 4. The 026 which infected two infants in the baby ward appeared to have spread from one infant to the other.

In the second interim period the three in-patients infected with $\mathrm{O} 55$ were in the baby ward and again the infection appeared to spread from one to the other. This organism persisted in the ward into the third epidemic period and infected two of those who later excreted 0119.

Evidence of Cross-infection. There were 23 infants infected with $\mathrm{O} 119$ during the main part of the first epidemic. Therefore the organism must have passed from one child to another at least 22 times; there was also evidence of cross-infection twice with 0111 and once with 0128 . That is at least 25 incidents of cross-infection among 51 infants in 16 weeks. During the second epidemic there were 13 crossinfections due to $\mathrm{O} 119$ and one due to $\mathrm{O} 26$ among 47 infants in 11 weeks. In the three weeks of the third epidemic there were 18 at risk and three incidents of cross-infection. In the first interim period there were two examples due to $\mathrm{O} 128$ and in the second two due to O55. However, one other pathogenic type of Esch. coli was found in the ward during the second epidemic and three others during the second interim period without any spread.

Totalling up the number of days each child was at risk in the ward, there were 1,175 child-days in the first epidemic, 818 in the second and 231 in the third. Therefore there was one incident of crossinfection for every 47,58 and 77 child-days in the three epidemics respectively.

These facts show a decreasing incidence of crossinfection. This could be due either to preventive measures or to decreasing virulence and infectivity of the organism. Table 1 does not show any decline in the incidence of symptoms in the later epidemics nor do the mortality figures suggest any decrease in the virulence of the organism as the type of infants at risk were very similar throughout the whole period. Therefore it was felt that the improved control of the infections was due to the measures taken to cut down cross-infection.

Improvements to Reduce Cross-infection. The general precautions against infectious diseases in force at the time of the first epidemic have been described earlier. During the first interim period the following improvements were made: (1) ample paper hand towels were provided; (2) taps were adjusted to be easily operated by elbow; (3) cello-

TABLE 4

NUMBERS OF INFANTS INFECTED WITH VARIOUS ESCH. COLI TYPES

\begin{tabular}{|c|c|c|c|c|c|c|c|c|c|c|c|c|}
\hline \multirow{2}{*}{\multicolumn{2}{|c|}{$\begin{array}{l}\text { Esch. coli } \\
\text { Type }\end{array}$}} & & \multicolumn{2}{|c|}{$\begin{array}{l}\text { 1st O119 Epidemic } \\
\text { Sept. 1954-Jan. } 1955\end{array}$} & \multicolumn{2}{|c|}{ Interval } & \multicolumn{2}{|c|}{$\begin{array}{l}\text { 2nd O119 Epidemic } \\
\text { June-Aug. } 1955\end{array}$} & \multicolumn{2}{|c|}{ Interval } & \multicolumn{2}{|c|}{$\begin{array}{c}\text { 3rd O119 Epidemic } \\
\text { Feb. } 1956\end{array}$} \\
\hline & & & I.P.* & O.P.† & I.P. & O.P. & I.P. & O.P. & I.P. & O.P. & I.P. & O.P. \\
\hline $\begin{array}{l}\text { O119 } \\
\text { O128 } \\
\text { O55 } \\
\text { O26 } \\
\text { O111 } \\
\text { O126 } \\
\text { O86 } \\
\text { O125 } \\
\text { O114 }\end{array}$ & $\begin{array}{l}\ldots \\
\ldots \\
\ldots \\
\ldots \\
\ldots \\
\ldots \\
\ldots\end{array}$ & $\begin{array}{c}\ldots \\
\ldots \\
\ldots \\
\ldots \\
\ldots \\
\ldots \\
\ldots\end{array}$ & $\begin{array}{r}28 \\
3 \\
1 \\
3 \\
3 \\
0 \\
0 \\
1 \\
0\end{array}$ & $\begin{array}{l}1 \\
3 \\
2 \\
0 \\
0 \\
1 \\
1 \\
0 \\
0\end{array}$ & $\begin{array}{l}0 \\
5 \\
2 \\
0 \\
0 \\
0 \\
0 \\
0 \\
0\end{array}$ & $\begin{array}{l}0 \\
2 \\
1 \\
1 \\
0 \\
0 \\
0 \\
0 \\
0\end{array}$ & $\begin{array}{r}15 \\
0 \\
2 \\
2 \\
0 \\
0 \\
2 \\
0 \\
0\end{array}$ & $\begin{array}{l}5 \\
2 \\
0 \\
1 \\
1 \\
4 \\
0 \\
0 \\
0\end{array}$ & $\begin{array}{l}1 \\
1 \\
3 \\
1 \\
2 \\
0 \\
0 \\
0 \\
1\end{array}$ & $\begin{array}{l}7 \\
2 \\
2 \\
1 \\
2 \\
0 \\
0 \\
0 \\
0\end{array}$ & $\begin{array}{l}4 \\
0 \\
2 \\
0 \\
0 \\
0 \\
0 \\
0 \\
0\end{array}$ & $\begin{array}{l}0 \\
0 \\
0 \\
0 \\
0 \\
0 \\
0 \\
0 \\
0\end{array}$ \\
\hline
\end{tabular}

* I.P. = In-patient in any ward of the hospital.

$\dagger$ O.P. $=$ Out-patient. 
phane was incorporated in face masks; (4) nurses responsible for making feeds no longer had nursing duties in the ward, leaving one sister, two staff nurses and eight student nurses to look after 12 babies. This staff was no longer called upon to help at night in Out-patients or in emergencies in other wards, but worked only in the baby ward.

The major structural improvements could not be carried out till August and September, 1955, after the second epidemic. Then the sluice room was redesigned and unnecessary equipment removed. A large bucket sterilizer and an electric incinerator were installed. Once the former was working, a special bucket and lid for soiled clothes, linens and napkins was provided for each baby. In the sluice room the nurses, using large forceps, put the napkins into one large container and the soiled laundry into another, spraying Domitol into the containers before replacing the lids. The napkins went in the inner bags of the container direct to the laundry. The soiled linen container was emptied down a shute four times a day by the porters. All the linen was then sorted and dispatched to the laundry by separate external staff from a special room in the basement.

A modern stainless steel kitchen sink unit was installed and each baby was given an individual feed tray on which was put his own feed box and lid for bottle and individual teat bowl and lid. All were sterilized before each feed and kept on a separate shelf in a cupboard.

Special precautions against infection were instituted whenever a baby passed suspicious motions. These consisted in using soluble napkins which were burnt in the electric incinerator, soaking all linen in Domitol in a separate container kept on the balcony outside the sluice, providing separate examination trays containing an auriscope, stethoscope, spatulae and torch, and keeping feeds in a separate kitchen. In addition all infants with symptoms of gastroenteritis were treated with antibiotics, terramycin being usually chosen.

The effectiveness of these precautions has been further tested since the end of the period of this study when babies with gastro-enteritis due to Esch. coli $\mathrm{O} 127$ were admitted from the Maternity Unit. Although several babies became crossinfected, control was easy and no persistent epidemic occurred.

\section{Discussion}

Bacteriology. The association of certain types of Esch. coli with gastro-enteritis in infants is now well established. The subject has been thoroughly reviewed by Smith (1955). While some cases of gastro-enteritis may be caused by viruses or some yet unidentified agent there is no doubt in our minds that other cases are not only associated with the presence of certain Esch. coli types in the intestine but are actually caused by these organisms.

The first attempts to classify Esch. coli isolated from cases of gastro-enteritis used biochemical criteria but this method was insufficiently precise to definitely distinguish pathogenic from non-pathogenic strains. The serological classification of Esch. coli by Kauffmann (1947) based on O, K and $\mathrm{H}$ antigens allowed a much more exact identification. By the end of 1953 there were already $126 \mathrm{O}$ groups, $62 \mathrm{~K}$ antigens and $34 \mathrm{H}$ antigens recognized (Kauffmann, 1954). In Esch. coli isolated in gastroenteritis the $K$ antigens are of the $B$ type, except in $\mathrm{O} 25$ strains in which they are of $\mathrm{L}$ type, and a constant B antigen appears to be associated with each $\mathrm{O}$ group. Each $\mathrm{OB}$ type may have variable $\mathrm{H}$ (flagellar) antigens or none at all. Variation in $\mathrm{H}$ antigen, then, allows subdivision of $\mathrm{OB}$ types which is useful in epidemiological studies.

Numerous papers incriminating at least 12 different $\mathrm{O}$ types of Esch. coli as causes of gastroenteritis have been published. Kauffmann (1947) showed that strains collected from gastro-enteritis cases by Adam as early as 1923 and 1927 were type 0111:B4 while those isolated by Bray (1945) were type O55:B5. Types O26:B6, O86:B7, $\mathrm{O} 125: \mathrm{B} 15, \mathrm{O} 126: \mathrm{B} 16$ and $\mathrm{O} 128: \mathrm{B} 12$ were found later by Taylor and Charter (1952) in infants with gastro-enteritis. More recently cases due to type O127:B8 have been described by Cooper, Walters, Keller, Sutherland and Wiseman (1955) and due to 0114 by Rogers and Cracknell (1956) and Charter (1956).

Esch. coli later shown to be type O119:B14 were first isolated from calves with 'scours' (Wramby, 1948). Scours is a disease of calves in which fever, diarrhoea and pneumonia occur in the first few days after birth. Smith (1953) reported the association of this organism with diarrhoea in 21 infants in Aberdeen during 1952. Thomas and Charter (1956) record the isolation of $\mathrm{O} 119$ from one infant but no other paper describing this organism as a cause of epidemics of gastro-enteritis is known to us though a number of outbreaks have occurred (Smith, 1955).

The biochemical reactions of the Aberdeen strains, where tested, were similar to those of the strains isolated by us in Westminster and the strains in both epidemics were type $\mathrm{H} 6$ which is the most commonly found flagellar antigen in $\mathrm{O} 119$ strains. The virulence of the Aberdeen 0119 organisms was comparatively like that of our strains. No deaths occurred in the 21 Aberdeen cases while three deaths 
occurred in our series of 61 cases and two of those who died had other severe disabilities. In both series the infectivity rate was high. Smith (1953) states that 10 out of 25 contacts became infected. In our first epidemic $45 \%$, in our second $30 \%$ and in our third $22 \%$ of the infants in the ward exposed to infection were found to be excreting the organism.

The reasons for incriminating Esch. coli $\mathrm{O} 119$ as the cause of gastro-enteritis in our cases were as follows: (a) out of the 20 cases of definite gastroenteritis in the three epidemics, 12 developed symptoms within two days of the first demonstration of Bact. coli O119; (b) all had almost pure cultures of the organism from their faeces at the time that they were ill. In convalescence, however, the organism usually became gradually less predominant; (c) there was a parallelism in the ward between the incidence of positive swabs and cases of gastro-enteritis (Figs. 2 and 4); (d) Esch. coli 0119 was cultured from all cases of gastro-enteritis in the ward during the epidemics and no other causal organism was found.

In contrast was our finding of negative faecal swabs not only in hundreds of babies without diarrhoea at this hospital, but also in more than 800 swabs from infants in the maternity units mentioned earlier.

Prevention of Cross-infection. The improvements in construction, nursing care and drug treatment in the baby ward, already described, undoubtedly reduced cross-infection but did not at once prevent fresh cases, even though stools were rapidly cleared of all Esch. coli (Figs. 1 and 3). This indicates the extreme infectivity of the pathogenic Esch. coli which together with the short incubation period allows epidemics to occur even in carefully managed baby wards and leaves no time for delay in taking extra precautions. This great infectivity has been commented on by many authors including Rogers (1951) and Jameson, Mann and Rothfield (1954).

A child excreting the organism, whether with or without symptoms, is a danger to others and should be sought out and isolated. Ideally this requires an isolation-admission ward where children who have been in contact with gastro-enteritis or recently in other hospitals or day nurseries can be swabbed and observed for at least two days. Jameson et al. (1954) not only recommended this but did not allow infants who had been previously in a gastro-enteritis ward to be admitted for any condition to a ward other than a gastro-enteritis unit. This was because such infants may be continuous or intermittent carriers of pathogenic Esch. coli. For the same reason they did not allow infants who had been in a gastro-enteritis unit to be transferred to nurseries or convalescent homes. Several of our infants continued to excrete 0119 for about eight weeks and one infant with $\mathrm{O} 111$ infection was still excreting this organism after more than four months. We certainly agree that these infants should be nursed in isolation and we consider that excretors of pathogenic types of Esch. coli should be at once treated with larger than normal oral doses of antibiotics, such as terramycin, $50 \mathrm{mg}$./lb./day, or neomycin, $50 \mathrm{mg}$./lb./day. Sensitivity tests should be made on all strains isolated as there is considerable variation in sensitivity of these organisms to antibiotics and sulphonamides.

\section{Summary}

Three epidemics of gastro-enteritis due to Esch. coli $\mathrm{O} 119$ involved 45 babies in one ward. Twentyseven had symptoms and three died.

The short incubation period and high infectivity rate allowed the occurrence of these epidemics in spite of usual barrier nursing techniques and individual cubicles. Cross-infection was reduced by improved precautions and prompt administration of terramycin to all babies excreting the organism. Sensitivity tests proved useful in the choice of antibiotic. All the 0119 strains were resistant to sulphonamide and sensitive to chloramphenicol, aureomycin, streptomycin, neomycin and polymyxin.

In the 18 months' study 3,048 faecal specimens from 894 infants were examined. Apart from the 45 infants in the three Esch. coli O119 epidemics another 16 were found to be infected with 0119 and 61 with other pathogenic types of Esch. coli, including 18 with $\mathrm{O} 128,15$ with $\mathrm{O} 55$, nine with $\mathrm{O} 26$ and eight with 0111 .

We wish to thank Dr. I. M. Anderson, Dr. C. F. Harris, the Hon. Mrs. N. O. Richards, Mr. D. Levi and Mr. G. H. Macnab for their help and encouragement and their permission to report on their cases; Dr. Joan Taylor and Dr. J. Smith for much valuable advice and the supply of various typing antisera, and Miss Geraldine Coats for much hard work in performing the biochemical and sensitivity tests.

\section{REFERENCES}

Bray, J. (1945). J. Path. Bact., 57, 239

Charter, R. E. (1956). Ibid., 72, 33

Cooper, M. L., Walters, E. W., Keller, H. M., Sutherland, J. M. and Wiseman, H. J. (1955). Pediatrics, 16, 215.

Jameson, J. E., Mann, T. P. and Rothfield, N. J. (1954). Lancet, 2, 459.

Jewell, P. and Pearmain, G. E. G. (1954). J. clin. Path., 7, 308.

Kauffmann, F. (1947). J. Immunol., 57, 71.

- (1954). Enterobacteriaceae, 2nd ed. Ejnar Munksgaard, Copenhagen.

Rogers, K. B. (1951). Proc. roy. Soc. Med., 44, 519

Rogers, and Cracknell, V. M. (1956). J. Path. Bact., 72, 27.

Smith, J. (1953). Ibid., 66, 503.

1955). The Aetiology of Epidemic Infantile Gastro-enteritis. Royal College of Physicians, Edinburgh.

Taylor, J. and Charter, R. E. (1952). J. Path. Bact., 64, 715

Taylor, J. and Charter, R. E. (1952). J. Path. Bact., 64, 715. 339.

Thomas, M. E. M. and Charter, R. E. (1956). Brit med. J., 2, 339.
Topley, W. W. C. and Wilson, G. S. (1946). Principles of Bacteriology and Immunity, 3rd ed. Edward Arnold, London.

Wramby, G. (1948). Acta path. microbiol. scand., Suppl. 76. 